FESIOE

Fundación Emilio Soldevilla de la Economia de la Empresa

\section{Management Letters / Cuadernos de Gestión}

journal homepage: http://www.ehu.eus/cuadernosdegestion/revista/es/

ISSN: 1131-6837 / e-ISSN: 1988-2157

\title{
Non-monetary price perceived in e-peer-to peer accommodation. Airbnb guests' perspective
}

\section{Precio no monetario percibido en alojamientos e-peer-to-peer. La perspectiva de los huéspedes de Airbnb}

\author{
Inés Küster ${ }^{\star}$ Juan J. Pascual ${ }^{a}$ \\ a Agency Account Strategist Manager for Google Spain - Department of Marketing - University of Valencia - Ava Tarongers sn 46022 Valencia. - juanjo.pascual.saez@gmail.com
}

* Corresponding author: Department of Marketing - University of Valencia - Faculty of Economics, Ava Tarongers sn 46022 Valencia.-ines.kuster@uv.es - https://orcid. org/0000-0002-8688-9175

\section{A R T I C L E I N F O}

Received 22 April 2020,

Accepted 18 November 2020

Available online 11 January 2021

DOI: $10.5295 / \mathrm{cdg} .201290 \mathrm{ik}$

JEL CODES: M; M3; M0

\begin{abstract}
A B S T R A C T
Price is considered as a key variable in predicting buying behavior. However, few studies have focused on how non-monetary price is affected and can affect other components of the consumer endogenous variables. This paper seeks (1) to analyze the effects of antecedents of behavioural price (past experience, the benefits and risks of peer to peer accommodation services) on the guest perceived price, and (2) to determine the effect of this price and past experience on guest intentions. With a sample of 136 Airbnb guests and the use of SEM, results show that past experience, financial risk, and time risk influence the non-monetary perceived price. This price and past experience affect guest intentions. This paper tries to bridge certain gaps detected in the literature: (1) we propose to extend the two main factors underlined, considering non-monetary costs, (2) this paper focuses on peer consumers because there is a lack of specification in previous studies due to authors have not differentiated users into host or guest when they analyse intentions, (3) previous literature has research in Airbnb prices but not in the factors that affect price, not in behavioural price strategies, and (4) much of the work to date has been qualitative in nature, whereas this study takes a quantitative approach.
\end{abstract}

Keywords: Perceived non-monetary price; guests' intentions; eC2C accommodation; Airbnb

\section{R E S U M E N}

El precio se considera una variable clave a la hora de determinar el comportamiento de compra. Sin embargo, pocos estudios se han centrado en investigar cómo el precio no monetario se ve afectado y puede afectar otras variables endógenas del consumidor. Así, este trabajo persigue (1) analizar los antecedentes en el precio comportamental (experiencia previa, beneficios y riesgos de los servicios de alojamiento peer-to-peer), y (2) determinar el efecto de este precio no monetario y de la experiencia pasada en las intenciones del huésped. Con una muestra de 136 huéspedes de Airbnb y el uso de modelos de ecuaciones estructurales, los resultados muestran que la experiencia pasada, el riesgo financiero y el riesgo de tiempo influyen en el precio no monetario percibido. Este precio y la experiencia pasada influyen en las intenciones de los huéspedes. Así, a través de este manuscrito, se persiguen cubrir ciertos gaps detectados en la literatura: (1) proponemos ampliar los dos factores principales subrayados, considerando los precios no monetarios, (2) este trabajo se centra en los huéspedes debido a que estudios previos no han diferenciado entre anfitriones o huéspedes al analizar las intenciones, (3) si bien algunos trabajos previos han investigado sobre los precios de Airbnb, no han analizado los factores que los afectan, ni las estrategias de precios no monetarios, y (4) gran parte del trabajo, hasta la fecha, ha sido de naturaleza cualitativa, mientras que este estudio adopta un enfoque cuantitativo.

Palabras clave: Precio no monetario percibido; intenciones de los huéspedes; alojamientos eC2C; Airbnb 


\section{INTRODUCTION}

Peer to peer accommodation is related to the so-called sharing economy, the economy among individuals who rent their homes, cars, gardens, and even bikes and bicycles to gain something of money in difficult times. But, as Sigala (2017) states, it is advised that collaborative consumption will continue to rise after the economy is fully recovered and, hence, will disrupt traditional value chains and threaten companies that are being bypassed by customers who are connecting and buying with each other (Tussyadiah and Pesonen 2016). Because of online social network platforms, people easily share access to resources sitting idle, such as accommodation (i.e., short-term rentals), with one another (Tussyadiah and Pesonen 2016). The reason can be that the use of these platforms implies benefits such as convenience, easy choice, competitive factor, and access to a wide range of products and services (Laudon and Traver 2004).

Since its origins in 1995 of the hand of eBay (Laudon and Traver 2004), this business has been growing. Statista (2018) shows the countries with the most Airbnb listings as of August 2017 (US, France, Italy, Spain, and United Kingdom). The United States had the most Airbnb listings as of August 2017 with 660 thousand listings, followed by France with 48500, Italy with 340000, Spain with 245000, and the UK with 175000 (Statista 2018).

These data have provoked some interest in the academic community. Not in vain, in 2011, it was only possible to find a job in which Airbnb appears (Luchs et al. 2011); while in 2017, the figure reached 2970 papers that in some way or another focused their interest on this collaborative hosting model (according to Google Scholar's consultation).

In this sense, and because peer-to-peer (P2P) accommodations have grown exponentially, it is critical to understand motivations for guests to choose this kind of accommodation instead of a hotel (Belarmino et al. 2017; Volgger et al. 2019). It is possible to find studies that analyse the motivations or benefits of this accommodation alternative (Dolnicar and Talebi 2020), but according to Tussyadiah and Pesonen (2016), two main factors drive the use of this kind of accommodation: social appeal and economic appeal. This paper considers those guests that don't want to share the accommodation with other people, that choose it as a cheaper alternative instead to go to a hotel and look for full-accommodations (they book the entire house, apartment, flat). Because of this, this paper focuses on the economic appeal, relate to cost savings in those travelers that stay in an entire home or apartment. But, not in monetary cost-saving, but in the non-monetary costs linked to the consumption of this alternative of accommodation.

More specifically, this study focuses on Airbnb guests. In this sense, created in 2008, Airbnb's mission is "to create a world where people can belong when they travel by being connected to local cultures and having unique travel experiences". Its community marketplace offers access to millions of unique accommodations in more than 65,000 cities, 191 countries, and with more than 260 million Airbnb guest arrivals all-time (Airbnb 2018). Therefore, examining the factors that lead to guest behavioral intention to use $\mathrm{P} 2 \mathrm{P}$ accommodation goes beyond informing $\mathrm{P} 2 \mathrm{P}$ providers with important needs to fulfill in order to retain guests at the time that provides hotels with information regarding the service characteristics and competitive advantages of their competitor (Tussyadiah 2016). In this sense, assumed the importance of Airbnb, it is essential to examine which factors could affect intentions to book accommodation on this platform (Amaro, Andreu and Huang 2017). According to Gibbs et al. (2018, p. 46), "Understanding Airbnb prices not only provides insights of practical importance to hosts but also to researchers trying to understand the sharing economy accommodation phenomenon. While commercial accommodation providers are generally strategic and deliberate in their pricing, and can typically rely on operational as well as market data and staff expertise when making pricing decisions, it is not clear how Airbnb hosts set their prices and how perceptions of consumers' willingness to pay for specific accommodation attributes potentially influence their pricing decisions".

This study tries to a better understanding of Airbnb entire accommodations guests' decisions related to non-monetary price. In this sense, it tries to bridge certain gaps detected in the literature. First, and following Tussyadiah and Pesonen (2016), we propose to extend their two main factors underlined, considering non-monetary costs. This kind of customer values the cost-savings but not only they consider the monetary price that they pay relevant, but also the associated non-monetary costs (Abramova et al. 2017). As Nicolau et al. (2020) state, non-monetary components could explain a better consumer decision process than using only monetary measures. Second, this paper focuses on peer consumers because there is a lack of specification in previous studies due to authors have not differentiated users into host or guest when they analyse intentions (Tussyadiah 2016; Abramova et al. 2017). More specifically, this study focuses on peer consumers and tries to examine the antecedents and effects of non-monetary cost perceptions. Third, previous literature has research in Airbnb prices but not in the factors that affect price, not in behavioural price strategies (Gibbs et al. 2018). In sum, and as Liang et al. (2018) state, research on Airbnb has broadly focused on different areas, but none so far have addressed what factors influence Airbnb consumers' repurchasing behavior. Finally, much of the work to date has been qualitative in nature, whereas this study will take a quantitative approach.

In this sense, and in order to reach the objectives, this paper is structured as follows. After this introduction, in which the justification of the topic to be investigated has been established, in the second section, a review of the literature is carried out, where a model related to the non-monetary price in the perceptions of $\mathrm{P} 2 \mathrm{P}$ accommodation guests is presented and justified. The third section, methodology, explains the research carried on with a sample of 136 Airbnb guests that have used this accommodation platform to rent a full house, and in the fourth section, results are presented. The paper finishes with a fith section that includes conclusions, implications, and further research.

\section{NON-MONETARY PRICE IN P2P ACCOMMODATION GUESTS PERCEPTIONS}

Consistent with intention-based models, and in the context of social exchange theories, perceived value is one of the 
most relevant factors that influences the use of $\mathrm{P} 2 \mathrm{P}$ accommodation alternatives (Tussyadiah 2016; Amaro et al. 2017). Perceived value is defined as "consumers' overall assessment of the utility of a product based on perceptions of what is received and what is given" (Zeithaml 1988, p. 14). This perceived value is a multidimensional concept that incorporates four dimensions: emotional value, social value, and two types of functional value (price/value for money and performance/ quality). But as Deng and Pierskalla (2011) state, assessing the social or emotional aspect of perceived value may be more relevant than assessing the functional aspect of perceived value for some tourism products or activities that are partly or entirely free of charge. In this sense, Zeithaml (1988) states that the non-monetary price (perceived sacrifice) represents one of the dimensions related to perceived value. According to Petrick (2002), consumers consider non-monetary costs (bahavioural price) in their evaluation of the relationship quality-price paid. This behavioural price includes such things as time, search costs, brand image, and convenience. It is therefore a combination of both perceived monetary and non-monetary costs that equate to consumers' overall perceived sacrifice which, in turn, affects their perception of product or service value (Petrick 2002).

The study of Tussyadiah (2016) differentiates guests based on their chosen types of accommodation. The results revealed that social benefits influence guest satisfaction for those staying in a private room that involved cohabitation with hosts, but that this was an insignificant factor for guest satisfaction for those staying in an entire home or apartment. Other factors must be considered. As Forsythe et al. (2006) state, consumers strive to maximize the perceived value of their shopping experience by evaluating the advantages and disadvantages between the expected benefits and perceived risks associated with online shopping.

Hedonic price theory that states that the price of a product can be considered as a function of the measurable, utility-affecting attributes or characteristics of the product, explain these behaviours (Gibbs et al. 2018). As these authors state, an Airbnb accommodation listing, according to hedonic pricing theory, is, therefore, a pack of elements that influence the quality of the overall product and provide consumers with value and satisfaction. Although the most widely reported and significant factors are related to the physical characteristics of the offering, there are other factors not- physical characteristics related.

Therefore, focusing on non-monetary perceived price (as a component of perceived value), some antecedents as previous experience, benefits, and risks perceived are analysed (Agarwal and Teas 2001; Chen and Dubinsky 2003). At the same time, this paper studies the effect of previous experience and non-monetary prices on purchase intention. Following authors as Dodds and Monroe (1985), Petrick (2002), or Smith and Colgate (2007), this paper considers that behavioural price acts as a mediator of perceived benefits, previous experience, and perceived risks on buyer intention because more research is needed in this field. As Volgger et al. (2019) state, there is limited research on behaviour and profiles of Airbnb, and further research is needed.

\subsection{Antededents of non-monetary price}

Related to perceived benefits, Sheth (1983) proposes that, in traditional shopping formats, functional and hedonistic motivations drive the buying process. Functional motivations are related to comfort, variety, product quality and price, while non-functional or hedonistic motives are related to social and emotional needs (Bhatnagar and Ghose 2004). When referring to online purchases, some authors suggest that functional reasons include convenience (Korgaonkar and Wolin 2002), a greater selection of products or services (Rowley 2000); as well as unique offers of products or services and lower prices (Korgaonkar 1984). In this sense, and in the context of peer-to-peer exchanges, like Airbnb, Lampinen and Cheshire (2016) state that money is not the primary motivation to participate, altruistic, internal, hedonic aspects must be considered.

Following Childers et al. (2002), functional and hedonistic motives of online shopping are especially important predictors of attitudes towards online purchases and therefore towards buying intentions and recommendations. In this sense, the four emergent dimensions of the benefits perceived in online purchases that are included are the convenience, the selection of accommodations, the ease of buying a service, and the hedonism.

Convenience is considered as the possibility to buy almost at any time from a variety of sites without visiting a store. The ease of booking is considered as the attempt to avoid the physical and emotional discomfort of reservations in physical agencies. All these benefits are dominant reasons for booking without the need to go to stores (Korgaonkar and Wolin 2002, Bhatnagar and Ghose 2004). On the other hand, several publications point to hedonistic motives as an important factor for online shopping (Parsons 2002, Wolfinbarger and Gilly 2003). Not in vain, the study focused on Airbnb in the Caribbean found that, among others, convenience, personal and amenities services, significantly affect prices (Lorde et al. 2019). Additionally, and according to Guttentag (2019), Airbnb offers an alternative value proposition to guests centered around the potential for a more authentic local experience (hedonism). In this line, in a study with Airbnb users in South Korea, Stollery and Jun (2017) concluded that there is a positive influence of hedonic benefit on perceived value; and it could be translated to the behavioral price. These authors found that South Korean Airbnb guests find value in employing Airbnb because it permits them to have distinct and unique experiences, have fun and excitement and save money (Stollery and Jun 2017).

In this sense, the following hypotheses state the relationship related to perceived benefits when a guest books in Airbnb.

H1: Convenience influences positively behavioural price, in eP2P accommodation contexts (Airbnb)

H2: Hedonism influences positively behavioural price, in eP2P accommodation contexts (Airbnb)

H3: Booking facilities influence positively behavioural price, in eP2P accommodation contexts (Airbnb)

H4: Accommodations service selections influence positively behavioural price, in eP2P accommodation contexts (Airbnb) 
Related to online previous experience, Chen and Chen (2010, p. 29) define service experience "as the subjective personal reactions and feelings that are felt by consumers when consuming or using a service". This previous experience has an important influence on the consumer evaluation of a service. The authors probed the relationship between service experience and perceived value. Additionally, Gentile et al. (2007) argue that consumers process in a cognitive and affective way the information they receive from the website, through these interactions a remember is created in their memory, the formation of this is a process that accumulates over time.

Thus, and as proposed by Zeithaml (1988), consumers follow their experience environment (past experiences), to evaluate the different alternatives and make a purchase decision. As Petrick (2002) states, the effect of past experience on a tourist/guest is reflected in the feelings, behaviors and decisions about which leisure opportunities to consider (time, search costs, brand image and convenience as aspects of behavior price are some of them). This experience will affect the perception of the non-monetary price, as proposed in the following hypothesis.

H5: Past experiences influence positively behavioural price, in $e P 2 P$ accommodation contexts (Airbnb).

Within the online context, authors such as Zhou et al. (2007), Ling et al. (2010) or Rose et al. (2012) suggest that past experiences influence future online behavior. Recently, Jun (2020) found that the experience had a direct effect on the intention to use Airbnb. Therefore, past experiences may influence the purchase intention or recommendation of reservation and rental services on $\mathrm{C} 2 \mathrm{C}$ websites. In this way, the following hypothesis is presented.

H6: Past experiences influence positively guest intention, in eP2P accommodation contexts (Airbnb).

Related to perceived risk, consumers' perceived risk is a critical factor in their decision making, especially for heterogeneous and intangible products (Sharifpour et al. 2014), as Airbnb services (Stollery and Jun 2017). In the field of consumer behavior, the concept has been defined in various ways. Some authors define it as the possibility of losing and the negative consequences of making that purchase or consumption (Cunningham, 1967; Cox 1967, Campbell and Goodstein 2001).

After the seminal work of Bauer (1960), other authors have shown the influence of perceived risk on consumer purchasing decisions, acting as a purchase inhibitor (ie Park et al. 2005, Shin 2008). However, more recent articles include more complex and holistic models where the perceived risk is related to other constructs such as perceived value (Verhagen et al. 2006, Leonard 2012). It is in this aspect where our interest is focused. Specifically, how the perceived risk can affect the perception of behavioral prices of the $\mathrm{P} 2 \mathrm{P}$ guest. According to the results achieved by Amaro et al. (2017), perceived risk can not influence attitudes to the book Airbnb but can affect perceived value (behavioral price perceptions).
The perceived risk has been contextualized in the literature as a multidimensional construct (Campbell and Goodstein 2001). Thus, the literature contemplates various types of risk. In contexts of online purchase, studies such as those proposed by Forsythe et al. (2002) and Forsythe and Shi (2003) point to three emerging dimensions of perceived risk: financial risk, product/ service risk, and time risk (Forsythe and Shi 2003).

As indicated, the risk implies uncertainty about the result that will be obtained after deciding and the costs that this action could have on consumers (Campbell and Goodstein 2001). Within the online context, the level of perceived risk that customers associate with a possible purchase is higher in online purchases than in those made in traditional channels (Cunningham et al. 2005). It should be noted that perceived risk plays a particularly important role in the explanation of consumer behavior, since consumers intend to avoid errors to maximize the purchasing utility (Shin 2008).

In sum and following the proposal of Chen and Dubinsky (2003), the following hypotheses are established that indicate that the different types of perceived risk are one of the precursors of the perceived value of the non-monetary price in online purchases. In this sense, the following hypotheses are proposed.

H7: Financial risks influence negativaly behavioural price, in eP2P accommodation contexts (Airbnb).

H8: Service risks influence negativaly behavioural price, in eP2P accommodation contexts (Airbnb).

H9: Time risks influence negativaly behavioural price, in eP2P accommodation contexts (Airbnb).

\subsection{Non-monetary price and guest intentions}

Zeithaml (1988) argues that consumers evaluate what they give and what they receive subjectively when they buy a product/service. Addionally, Thaler (1985) states that perceived value is an important antecedent to influence the purchase intention of consumers. Therefore, the probability that the purchase intention increases, is greater when consumers acquire more benefits than they pay for a product (Dickson and Sawyer 1990). Petrick (2002) proposes that nonmonetary perceptions of price in its critical role are likely to influence consumers' purchase intention of tourism products. In this sense, Liu and Lee (2016), with a simple of 484 low-cost airline passengers found that behaviour price perceptions increase not only buyer intention but also revisit intention. In the $\mathrm{eC} 2 \mathrm{C}$ context, literature (i.e. Verhagen et al. 2006; Leonard 2012) has probed that perceived value dimensions (non-monetary price among others) affect guest intention. In sum, we state that behavior price would influence guest intentions to re-use Airbnb accommodation service and recommend it.

H10: Non-monetary price influences guest intentions, in eP2P accommodation contexts (Airbnb).

Figure 1 shows the theoretical framework with the 10 hypotheses raised. 


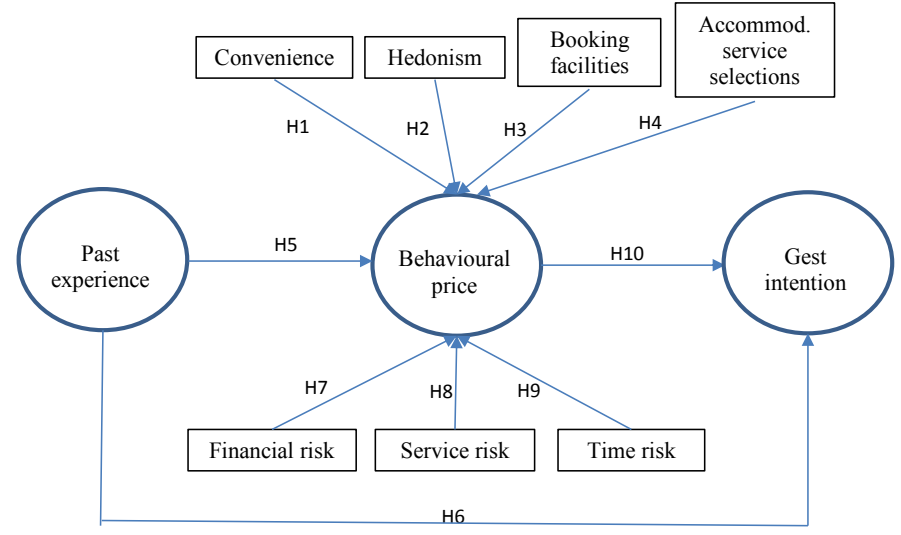

Figure 1

Theoretical framework

Source: Own elaborated

\section{METHODOLOGY}

\subsection{Population and sampling procedure}

The target population is formed by all those individuals residing in a specific geographical area, Valencia (Spain), over 18 years old, who reserve entire houses or apartments through Airbnb. "Spanish tourism sector is considered to be one of the most competitive markets in the world" (Berné et al. 2020, p. 114), and Valencia is considered one of the cities with a similar profile of Spain. Considering this population, an online questionnaire was designed and sent by e-mail, instant messages from social networks, WhatsApp, among others. The sampling procedure was an intentional or convenience sampling that was completed with a snowball sampling.

A total of 324 individuals were contacted. 14 left the questionnaire incomplete, so they were dismissed for carrying out the research. Of the remaining 298, 106 did not use this type of platform and, therefore, were discarded for the investigation. After applying the last filter, corresponding to the reservation of rooms through the Internet in the last 12 months, 20 individuals in the sample had not made reservations through the Internet at that time or had not purchased the entire house/apartment. Finally, a sample composed of 136 individuals was obtained. We only considered those correctly completed questionnaires that also met two filters: over 18 years old and had booked a complete apartment through Airbnb. This sample size is like others used in previous studies with Airbnb users (i.e. Poon and Huang 2017 or Wisker et al. 2019). In any case, results and their generalization must consider this sample size.

The profile that defines the sample reached is as follows. These are single individuals ( $72 \%$ of the sample) with full-time jobs ( $46 \%$ of the sample) and ages between 26 and 41 years (more than $80 \%$ of the sample), which are the ones with the most technology at their disposal (Smartphone, Tablet and computer), with an average income between 600 and 1800 euros (56\% of the sample) and with higher university studies ( $69 \%$ of the sample). Note that $62 \%$ of the sample that answered the complete questionnaire were women.

Therefore, this sample size allows us to approximate the $\mathrm{X}$-ray of the intention of use/consumption of this service by the Spanish target public, through the scales of measurement of the different constructs.

\subsection{Concepts measurement and their psychometric properties}

Following Yaghmaei (2003), concepts were measure through diverse multi-item scales based and adapted from the literature to guarantee that the instrument includes the content that it is intended to measure (content validity).

Table 1 shows the concepts and items analysed. All the scales are reflective, except for the variable past experience that is considered formative that is, indicators are causal where changes in them determine changes in the value of the latent variable (Diamantopoulos and Siguaw 2006).

Table 1

\section{Concepts measurement}

Concepts

Behavioural price

Petrick (2002)

Convenience

Forsythe et al. (2006)
It is easy to book.

It requires little effort to buy. It is easily affordable.

Book / rent with privacy from home.

I do not have to leave the house.

I can book / rent when I want

I avoid visiting physical agencies.
Service selection

Forsythe et al. (2006)
Accommodations from all the sites are available.

I can get good information online.

More wide selection of product.
Easy to book

Forsythe et al. (2006)
Hedonism

Forsythe et al. (2006)
I do not have to wait to be served.

I'm not embarrassed if I do not book.

For trying new experiences.

I can buy impulsively in response to an advertisement.

I can customize some services. 
Table 1

Concepts measurement (Cont.)

\begin{tabular}{|c|c|}
\hline Concepts & Initial items \\
\hline $\begin{array}{l}\text { Past experience } \\
\text { Havlena and Holbrook (1986), } \\
\text { Novak et al. (2000). } \\
\text { Khalifa and Liu (2007). }\end{array}$ & $\begin{array}{l}\text { Affective: } \\
\text { Unhappy } \\
\text { Sad } \\
\text { Annoying } \\
\text { Inactive } \\
\text { Calmed down } \\
\text { Relaxed } \\
\text { Addressed } \\
\text { Influenced } \\
\text { Cognitive: } \\
\text { When I made reservations for Internet accommodation } \\
\text { I have experienced a pleasant feeling. } \\
\text { Booking online satisfaction: } \\
\text { I am satisfied with my overall experience of booking rooms / apartments online. } \\
\text { I am satisfied with the experience prior to booking web sites for online shopping (search for products, the } \\
\text { quality of information). } \\
\text { I am satisfied with the experience of booking rooms / apartments on websites (reservations, payment } \\
\text { procedure). } \\
\text { I am satisfied with the experience after booking rooms / apartments on websites (customer service and after- } \\
\text { sales support). }\end{array}$ \\
\hline $\begin{array}{l}\text { Financial_Risk } \\
\text { Forsythe et al. (2006) }\end{array}$ & $\begin{array}{l}\text { I can not trust the online company. } \\
\text { Maybe I can not enjoy the service. } \\
\text { Maybe book something by accident. } \\
\text { My personal information may not be safe. } \\
\text { My credit card number may not be sure. }\end{array}$ \\
\hline $\begin{array}{l}\text { Service_Risk } \\
\text { Forsythe et al. (2006) }\end{array}$ & $\begin{array}{l}\text { Excessive exchange rate depending on the country of purchase } \\
\text { Many online offers are non-refundable } \\
\text { Hidden fees and payment in advance. } \\
\text { I can not confirm special requirements while booking online. }\end{array}$ \\
\hline $\begin{array}{l}\text { Time_Risk } \\
\text { Forsythe et al. (2006) }\end{array}$ & $\begin{array}{l}\text { Too long to make the reservation. } \\
\text { Difficulty finding appropriate websites. } \\
\text { The images take too long to load. }\end{array}$ \\
\hline $\begin{array}{l}\text { Guest intention } \\
\text { Pavlou (2003) }\end{array}$ & $\begin{array}{l}\text { Visit Airbnb website to find information about accommodation. } \\
\text { Reserve a room on Airbnb website } \\
\text { Book an apartment on Airbnb website } \\
\text { Recommend making a room reservation on Airbnb website. } \\
\text { Recommend making a reservation for an apartment on Airbnb website. }\end{array}$ \\
\hline
\end{tabular}

To try to avoid data normal distribution, to simultaneously assess the theoretical and the measurement model, and because the model has reflective and formative variables, we use Partial least squares (PLS), following the recommendations of Chin et al. (2003). Before testing the hypotheses, the measurement model was evaluated to analysis its psychometric characteristics (reliability and validity). Appendix 1 offers the results of this analysis.

First, no multicollinearity problems were detected: (VIF): Outer VIF Values (formatives) < 5 (Hair et al. 2011). After this, the significance of the reflective and formative variables was explored and declined those items not significant. We calculated again the VIF statistics to assure no collinearity problems.

Then and following Hulland (1999), we tested the validity and reliability of reflective constructs. In relation to item relia- bility, all the loadings of scales were near or surpassed the recommended value of 0.6 (Hair et al. 2014). Concerning construct reliability, all constructs were consistent since the composite reliability values exceeded the recommended value 0.7 .

Because of AVE (average variance of manifest variables extracted by constructs) was at least 0.5 , measures demonstrated their convergent validity, suggesting that more variance was explained than unexplained in the variables related with a given construct. Concerning discriminant validity, the square root of AVE is greater than the correlation between the construct and other constructs in the model (Carmines and Zeller 1979), and in all cases, the Heterotrait-Monotrait Ratios (HTMT) were far from 0.85 .

After verifying psychometric characteristics (reliability and validity), we calculated Q2 (blindfolding) and R2 to assess the 
accuracy of the estimation. We confirm that the relations in the model have predictive relevance due to all values of Q2 were positive. At the same time, the model offers high predictive power (all R2 were $>0.01$ ).

\section{RESULTS}

As stated before, through PLS, structural equation models were used to test the hypotheses. We used the bootstrapping approach. Thus, 5000 sample sets were created to obtain 5000 estimates for each parameter in the model. Each sample was obtained by sampling with a replacement of the original data set (Fornell and Larcker 1981; Chin 1998).

As Table 2 shows, in the proposed model, five relationships were found to be significant. Except for 5 relationships $(\mathrm{H} 1, \mathrm{H} 2$, $\mathrm{H} 3, \mathrm{H} 4$ and H8), the standardized regression coefficients of the other hypotheses are significant and allow to support these hypotheses (H5, H6, H7, H9, and $\mathrm{H} 10$ ).

Table 2

Hypotheses test

\begin{tabular}{|c|c|c|c|c|}
\hline Hypothesis & Description & B & $\mathrm{t}$ & Supported \\
\hline H1 & $\begin{array}{l}\text { Convenience }-> \\
\text { Behavioural price }\end{array}$ & 0.0076 & 0.1255 & Not \\
\hline $\mathrm{H} 2$ & $\begin{array}{l}\text { Hedonism }-> \\
\text { Behavioural price }\end{array}$ & -0.0903 & 1.7189 & Not \\
\hline H3 & $\begin{array}{l}\text { Booking facilities -> } \\
\text { Behavioural price }\end{array}$ & -0.0211 & 0.3223 & Not \\
\hline $\mathrm{H} 4$ & $\begin{array}{l}\text { Accommodations } \\
\text { service selections -> } \\
\text { Behavioural price }\end{array}$ & -0.0452 & 0.7162 & Not \\
\hline $\mathrm{H} 5$ & $\begin{array}{l}\text { Past experience }-> \\
\text { Behavioural price }\end{array}$ & $0.4621^{\star *}$ & 3.614 & Yes \\
\hline H6 & $\begin{array}{l}\text { Past experience -> } \\
\text { Guest intentions }\end{array}$ & $0.4913^{\star *}$ & 6.7443 & Yes \\
\hline $\mathrm{H} 7$ & $\begin{array}{l}\text { Financial risk -> } \\
\text { Behavioural price }\end{array}$ & $-0.2531^{\star *}$ & 2.7977 & Yes \\
\hline $\mathrm{H} 8$ & $\begin{array}{l}\text { Service risk -> } \\
\text { Behavioural price }\end{array}$ & 0.1762 & 1.9168 & Yes \\
\hline H9 & $\begin{array}{l}\text { Time risk -> } \\
\text { Behavioural price }\end{array}$ & $-0.2327^{\star *}$ & 2.599 & Yes \\
\hline $\mathrm{H} 10$ & $\begin{array}{l}\text { Behavioural price -> } \\
\text { Guest intentions }\end{array}$ & $0.2542^{\star *}$ & 3.7537 & Yes \\
\hline
\end{tabular}

${ }^{\star} \mathrm{p}<0.05 ;{ }^{* *} \mathrm{p}<0.01$

BEHAVIOR PRICE (BP) R Square $=0.3721$; Q Square $=0.3198$

GUEST INTENTION R Square $=0.4345$; $\mathrm{Q}$ Square $=0.1969$

As stated before, all the variances of the dependent latent variables exceed 0.1 value $\left(\mathrm{R}^{2}\right)$, following Chin (1998)'s recommendation. That is, the model presents a good fit and right $\mathrm{R}^{2}$ values for the structural equations, guaranteeing the predictive value of the dependent variables $\left(\mathrm{R}^{2}\right.$ behavior price $=0.37 ; \mathrm{R}^{2}$ guest intention=0.43).

Regarding the predictive relevance, the objective is to determine if the estimation of the lost values that considers the information of the model is better than the estimate that obviates this estimate (substitution by the average). In this sense, the
$\mathrm{Q}^{2}$ statistic is constructed in such a way that it will be positive when the error committed with the information of the model is smaller; then there will be predictive relevance. In our case, all values are positive $\left(\mathrm{Q}^{2}\right.$ behaviour price $=0.3198$; $\mathrm{Q}^{2}$ guest intentions $=0.1969)$ (Table 2).

The results obtained reveal the decisive role played by previous experience in online bookings on the behavioral price component of the perceived value $(\mathrm{H} 5)\left(\mathrm{B}_{\mathrm{H} 5}=0.46, \mathrm{t}=3.614\right)$ and on the intention to reserve and recommend $(\mathrm{H} 6)\left(\mathrm{B}_{\mathrm{H} 6}=0.49\right.$, $t=6.744$ ). But must be noticed that past experience has not only a direct effect of guest intentions (H6) but also an indirect effect because this previous experience affects the behavioural price component (H5) and this behavioural price influences guest intentions $(\mathrm{H} 10)\left(\mathrm{B}_{\mathrm{H} 10}=0.2542, \mathrm{t}=3.754\right)$.

As for the components of the perceived benefits, the results show that the functional and hedonic components do not affect the behavioral price dimension of the perceived value, since the related hypotheses $(\mathrm{H} 1, \mathrm{H} 2, \mathrm{H} 3$ and $\mathrm{H} 4)$ are not supported.

Finally, the results show the negative relationship between two of the three types of online risk and the behavioral price dimension of the perceived value $(\mathrm{H} 7$ and $\mathrm{H} 9)\left(\mathrm{B}_{\mathrm{H} 7}=-0.25\right.$, $\left.\mathrm{t}=2.798 ; \mathrm{B}_{\mathrm{H} 9}=-0.23, \mathrm{t}=2.599\right)$. As in the case of experience, these two kinds of risks (financial risk and time risk) can affect guest intentions indirectly because they influence on non-monetary price perceptions and these perceptions influence on guest intentions (H6).

In sum, preivious experience, financial risk, and time risk, through their effect on the non-monetary price, explains $43.45 \%$ of guests' intentions and $37.21 \%$ of the non-monetary price. In this model, it should also be considered the probable casue of mediation of behavioural price between previous experience, financial risk, and time risk with the guest's intentions.

\section{CONCLUSIONS, IMPLICACTIONS AND FURTHER RESEARCH}

This paper focuses on Airbnb guests that book a full house/ apartment, intending to investigate the role of non-monetary price on gests' future intentions. Results confirm that previous experience and some perceived risks influence non-monetary price perceptions, and this affects guest intentions. The main conclusions and implications that must be understood under the premise of the sample size obtained are as follows.

\subsection{Conclusions and implications}

The results of this investigation reveal that there are significant differences between antecedents and effects of non-monetary price. More specifically, the results show that the previous experience and the behavioral price have a direct and positive effect on the intention of booking on Airbnb. In this sense, three main conclusions can be obtained as explained below.

First, the model shows the determining role of previous experience in two ways. First, past experience shows a direct effect on the intention of booking apartments and complete apartments through Airbnb. This result is consistent with previous studies in online contexts (for example, Rose et al. 2012). Second, previous 
experience has an indirect effect through the positive effect of previous experience on the non-monetary price. In this sense, behavioural price plays a mediator role in the effect of past experience and the Airbnb guest intentions. In sum, the previous experience could be considered one of the strongest variables affecting consumers' decision-making process, especially when consumers purchase high-risk travel products as Airbnb (Jun 2020).

Secondly, and with respect to the dimensions of the perceived benefits (convenience, hedonism, ease of reservation, and selection of services), they do not show a significant relationship with the perceived behavioral price. Therefore, these factors can not be considered to affect this component of value concerning the use of this type of services in $\mathrm{eC} 2 \mathrm{C}$ environments. The characteristics of this type of accommodation could explain the results obtained (Jun 2020).

Finally, the tested model shows that certain perceived risks (financial and time) negatively influence the value of the non-monetary price received in the Airbnb reserves. As Poon and Huang (2017) state, compared to traditional accommodation, Airbnb involves more risks and is often suggested for adventurous travelers. Our study findings are consistent with previous research where visitors consider certain risks in their purchase decision-making (Sharifpour et al. 2014).

Because of the results achieved; it is possible to establish the following implications.

For the development of eC2C business of reservation of rooms, companies should focus on minimizing risks, especially financial ones as these decrease the perceived value and therefore the intention of reservation. Our results suggest that Airbnb companies should analyse the effects of each kind of perceived risks rather than consider overall perceived risk. Airbnb users are concerned about aspects related to financial risks: the host credibility, the security to book what they want or the possibility that their personal/financial information is not safe, and they may have problems). The Airbnb company needs to provide guarantees to its guests that the Airbnb guests will be taken care of by the company in case something happens. Additionally, Airbnb guests are concerned with some features related to time risk: too long to make the reservation, difficulty to find appropriated accommodation options or images not available). In this sense, Airbnb company should focus on these aspects to reduce time risk.

Regarding the quality and reputation components, the Airbnb company and hosts should not focus on maximizing their value, since they do not have a direct relationship with the intention of reserving rooms in $\mathrm{eC} 2 \mathrm{C}$ environments, being able to dedicate the resources to other more lucrative functions. Specifically, it would be interesting to focus on generating pleasant experiences as these increase both the perceived value and the purchase intention, both directly and indirectly; the perceived risks will decrease and the non-monetary price perceptions that significantly affect the reserve intention will increase. In this sense, Airbnb company and hosts should focus on to get that Airbnb guests, in the future, visit Airbnb website to find information about accommodations, reserve a room or book an apartment on Airbnb website or recommend making a room/apartment reservation on Airbnb website.

\subsection{Limitations and further research}

The findings and contributions of this work present certain limitations, which have been considered for the interpretation of the results, and these limitations may provide some opportunities for future research.

First, the sampling that has been done to obtain the data has been a convenience sampling. On the other hand, a greater geographic scope can help to understand cross-cultural differences.

Also, the study has focused only on the demand perspective and when talking about $\mathrm{eC} 2 \mathrm{C}$ business it may be interesting to have a supply perspective.

Finally, only a limited number of endogenous consumer variables have been considered, so future research may focus on adding variables to the model to test a holistic model that is as true as possible to reality. For example, future research could considerer travel profiles or demographic variables related to Airbnb guests.

\section{DECLARATION OF INTEREST}

The authors certify that they have NO affiliations with or involvement in any organization or entity with any financial interest (such as honoraria; educational grants; participation in speakers' bureaus; membership, employment, consultancies, stock ownership, or other equity interest; and expert testimony or patent-licensing arrangements), or non-financial interest (such as personal or professional relationships, affiliations, knowledge or beliefs) in the subject matter or materials discussed in this manuscript.

\section{REFERENCES}

Abramova, O., Krasnova, H., and Tan, C. W., 2017. How much will you pay? Understanding the value of information cues in the sharing economy. European Conference on Information Systems (ECIS), 1011-1028.

Airbnb, 2018: Fast facts. In press.atairbnb.com/fast-facts. Retrieved February, 18.

Agarwal, S., and Teas, R. K., 2001. Perceived value: mediating role of perceived risk. Journal of Marketing theory and Practice, 9(4), 1-14.

Amaro, S., Andreu, L., and Huang, S., 2017. Generation Y Travelers' Intentions to Book Airbnb Accommodation: An Abstract. In Marketing at the Confluence between Entertainment and Analytics, 43-44. Springer, Cham.

Bauer, R. A., 1960. Consumer behavior as risk-taking. In R. S. Hancock (Ed.), Dynamic marketing for a changing world. Chicago: American Marketing Association.

Belarmino, A., Whalen, E., Koh, Y., and Bowen, J. T., 2017. Comparing guests' key attributes of peer-to-peer accommodations and hotels: mixed-methods approach. Current Issues in Tourism, 1-7.

Berné, C., Ciobanu, A. V., and Pedraja, M., 2020. The electronic word of mouth as a context variable in the hotel management decision-making process. Cuadernos de Gestión, 20 (1), 111-136.

Bhatnagar, A., and Ghose, S., 2004. Segmenting consumers based on the benefits and risks of Internet shopping. Journal of Business Research, 57(12), 1352-1360.

Campbell, M. C., and Goodstein, R. C., 2001. The moderating effect of perceived risk on consumers' evaluations of product incongruity: Preference for the norm. Journal of Consumer research, 28(3), 439-449. 
Carmines, E. G., and Zeller, R. A., 1979. Reliability and validity assessment (Vol. 17). Thousand Oaks, Sage.

Chen, C. F., and Chen, F. S., 2010. Experience quality, perceived value, satisfaction and behavioral intentions for heritage tourists. Tourism management, 31(1), 29-35.

Chen, Z., and Dubinsky, A. J., 2003. A conceptual model of perceived customer value in e-commerce: A preliminary investigation. Psychology and Marketing, 20(4), 323-347.

Childers, T. L., Carr, C. L., Peck, J., and Carson, S., 2002. Hedonic and utilitarian motivations for online retail shopping behavior. Journal of retailing, 77(4), 511-535.

Chin, W. W., 1998. The Partial Least Squares Approach to Structural Equation Modeling. Modern Methods for Business Research, In: G. A. Marcoulides, Ed., Lawrence Erlbaum Associates Publisher, New Jersey, 295-336.

Chin, W.W.; Marcolin, B.L. and Newsted, P.R., 2003. A Partial Least Squares Latent Variable Modelling Approach for Measuring Interaction Effects: Results from a Monte Carlo Simulation Study and an Electronic Mail Emotion/ Adoption Study. Information Systems Research, 14 (2), 189-217. doi:10.1287/isre.14.2.189.16018

Cox, D. F., 1967. Risk taking and information handling in consumer behavior. Boston: Division of Research, Graduate School of Business Administration, Harvard University.

Cunningham, L. F., Gerlach, J., and Harper, M. D., 2005. Perceived risk and e-banking services: An analysis from the perspective of the consumer. Journal of Financial Services Marketing, 10(2), 165-178.

Cunningham, S. M., 1967. The major dimensions of perceived risk. In D. F. Cox (Ed.), Risk taking and information handling in consumer behavior. Cambridge, Mass.: Harvard University Press, 82-108.

Deng, J., and Pierskalla, C., 2011. Impact of past experience on perceived value, overall satisfaction, and destination loyalty: A comparison between visitor and resident attendees of a festival. Event Management, 15(2), 163-177.

Diamantopoulos, A., and Siguaw, J. A., 2006. Formative Versus Reflective Indicators in Organizational Measure Development: A Comparison and Empirical Illustration. British Journal of Management, 17, 263-282.

Dickson, P. R., and Sawyer, A. G., 1990. The price knowledge and search of supermarket shoppers. Journal of Marketing, 42-53.

Dodds, W. B., andd Monroe, K. B., 1985. The effect of brand and price information on subjective product evaluation. Advances in Consumer Research.

Dolnicar, S., and Talebi, H., 2020. Does hosting on Airbnb offer hosts vacation-like benefits? Proposing a reconceptualization of peer-topeer accommodation. Journal of Hospitality and Tourism Management, 43, 111-119.

Fornell, C., and Larcker, D. F., 1981. Structural equation models with unobservable variables and measurement error: Algebra and statistics. Journal of marketing research, 382-388.

Forsythe, S.M., Petee, T., and Kim, J.-O., 2002. Modeling Consumer Behavior in On-Line Environments: Scale Development. (Annual Reports). Spring House, PA: National Textile Center.

Forsythe, S.M., and Shi, B., 2003. Consumer Patronage and Risk Perceptions in Internet Shopping. Journal of Business Research, 56(11), 867-875.

Forsythe, S., Liu, C., Shannon, D., and Gardner, L. C., 2006. Development of a scale to measure the perceived benefits and risks of online shopping. Journal of Interactive Marketing, 20(2), 55-75.

Gentile, C., Spiller, N., and Noci, G., 2007. How to Sustain the Customer Experience: An Overview of Experience Components that Co-create Value with the Customer. European Management Journal, 25(5), 395-410.

Gibbs, C., Guttentag, D., Gretzel, U., Morton, J., and Goodwill, A., 2018. Pricing in the sharing economy: a hedonic pricing model applied to Airbnb listings. Journal of Travel and Tourism Marketing, 35(1), 46-56.
Guttentag, D., 2019. Progress on Airbnb: a literature review. Journal of Hospitality and Tourism Technology, 10 (4), 814-844.

Hair Jr, F., Sarstedt, J., Hopkins, M. and Kuppelwieser, V., 2014. Partial least squares structural equation modeling (PLS-SEM) An emerging tool in business research. European Business Review, 26(2), 106-121.

Hair, J. F., Ringle, C. M., and Sarstedt, M., 2011. PLS-SEM: Indeed a silver bullet. Journal of Marketing theory and Practice, 19(2), $139-152$

Havlena, W. J., and Holbrook, M. B., 1986. The varieties of consumption experience: comparing two typologies of emotion in consumer behavior. Journal of Consumer Research, 13(3), 394-404.

Hulland, J., 1999. Use of Partial Least Squares (PLS) in Strategic Management Research: A Review of Four Recent Studies. Strategic Management Journal, 20(2), 195-204.

Jun, S. H., 2020. The Effects of Perceived Risk, Brand Credibility and Past Experience on Purchase Intention in the Airbnb Context. Sustainability, 12(12), 5212.

Khalifa, M., and Liu, V., 2007. Online consumer retention: contingent effects of online shopping habit and online shopping experience. European Journal of Information Systems, 16(6), 780-792.

Korgaonkar, P. K., 1984. Consumer shopping orientations, non-store retailers, and consumers' patronage intentions: a multivariate investigation. Journal of the Academy of Marketing Science, 12(1-2), 11-22.

Korgaonkar, P., and Wolin, L. D., 2002. Web usage, advertising, and shopping: relationship patterns. Internet Research, 12(2), 191-204.

Lampinen, A., and Cheshire, C., 2016. Hosting via Airbnb: Motivations and financial assurances in monetized network hospitality. In Proceedings of the 2016 CHI conference on human factors in computing systems, May, 1669-1680.

Laudon, K. C., and Traver, C. G., 2004. E-commerce: Business. Technology, Society, 2.

Leonard, L. N. K., 2012. Attitude influencers in c2c e-commerce: buying and selling. The Journal of Computer Information Systems, 52(3), 11-17.

Liang, L. J., Choi, H. C., and Joppe, M., 2018. Exploring the relationship between satisfaction, trust and switching intention, repurchase intention in the context of Airbnb. International Journal of Hospitality Management, 69, 41-48.

Ling, K. C., Chai, L. T., and Piew, T. H., 2010. The effects of shopping orientations, online trust and prior online purchase experience toward customers' online purchase intention. International Business Research, 3(3), 63.

Liu, C. H. S., and Lee, T., 2016. Service quality and price perception of service: Influence on word-of-mouth and revisit intention. Journal of Air Transport Management, 52, 42-54.

Lorde, T., Jacob, J., and Weekes, Q., 2019. Price-setting behavior in a tourism sharing economy accommodation market: A hedonic price analysis of AirBnB hosts in the caribbean. Munich Personal RePEc Archive/MPRA, paper No. 95475.

Luchs, M., Naylor, R. W., Rose, R. L., Catlin, J. R., Gau, R., Kapitan, S., and Weaver, T., 2011. Toward a sustainable marketplace: Expanding options and benefits for consumers. Journal of Research for Consumers, 19, 1.

Nicolau, J. L., Mellinas, J. P., and Martín-Fuentes, E., 2020. Satisfaction measures with monetary and non-monetary components: hotel's overall scores. International Journal of Hospitality Management, 87, 102497.

Novak, T. P., Hoffman, D. L., and Yung, Y. F., 2000. Measuring the customer experience in online environments: A structural modeling approach. Marketing science, 19(1), 22-42.

Park, J., Lennon, S. J., and Stoel, L., 2005. On-line product presentation: Effects on mood, perceived risk, and purchase intention. Psychology and Marketing, 22(9), 695-719. 
Parsons, A.G., 2002. Non-Functional Motives for Online Shoppers: Why We Click. Journal of Consumer Marketing, 19(5), 380-392.

Pavlou, P. A., 2003. Consumer acceptance of electronic commerce: integrating trust and risk with the technology acceptance model. International journal of electronic commerce, 7(3), 101-134.

Petrick, J.F., 2002. Development of a Multi-Dimensional Scale for Measuring the Perceived Value of a Service. Journal of Leisure Research, 34(2), 119-134.

Poon, K. Y., and Huang, W. J., 2017. Past experience, traveler personality and tripographics on intention to use Airbnb. International Journal of Contemporary Hospitality Management, 29(9), 2425-2443.

Rose, S., Clark, M., Samouel, P., and Hair, N., 2012. Online customer experience in e-retailing: An empirical model of antecedents and outcomes. Journal of Retailing, 88(2), 308-322.

Rowley, J., 2000. Product Searching with Shopping Bots. Internet Research, 10(3), 203-214.

Sharifpour, M., Walters, G., Ritchie, B.W., Winter, C., 2014. Investigating the role of prior knowledge in tourist decision making: A structural equation model of risk perceptions and information search. Journal of Travel Research, 53, 307-322

Sheth, J. N., 1983. Emerging trends for the retailing industry. Journal of Retailing, 59(3), 6-18.

Shin, D. H., 2008. Understanding purchasing behaviors in a virtual economy: Consumer behavior involving virtual currency in Web 2.0 communities. Interacting with computers, 20(4-5), 433-446.

Sigala, M., 2017. Collaborative commerce in tourism: implications for research and industry. Current Issues in Tourism, 20(4), 346-355

Smith, J. B., and Colgate, M., 2007. Customer value creation: a practical framework. The journal of marketing theory and practice, 15(1), 7-23.

Statista, 2018. Countries with the most Airbnb listings as of August 2017. In www.statista.com
Stollery, A., and Jun, S. H., 2017. The antecedents of perceived value in the Airbnb context. Asia Pacific Journal of Innovation and Entrepreneurship, 11(3), 391-404

Thaler, R., 1985. Mental accounting and consumer choice. Marketing Science, 4(3), 199-214.

Tussyadiah, I. P., 2016. Factors of Satisfaction and Intention to Use Peerto-Peer Accommodation. International Journal of Hospitality Management, 55, 70-80.

Tussyadiah, I. P., and Pesonen, J., 2016. Drivers and barriers of peer-topeer accommodation stay-an exploratory study with American and Finnish travellers. Current Issues in Tourism, 1-18.

Verhagen, T., Meents, S., and Yao-Hua, T., 2006. Perceived risk and trust associated with purchasing at electronic marketplaces. European Journal of Information Systems, 15(6), 542-555.

Volgger, M., Taplin, R., and Pforr, C., 2019. The evolution of 'Airbnbtourism': Demand-side dynamics around international use of peerto-peer accommodation in Australia. Annals of Tourism Research, $75,322-337$.

Wisker, Z. L., Kadirov, D., and Bone, C., 2019. Modelling P2P Airbnb online host advertising effectiveness: the role of emotional appeal information completeness creativity and social responsibility. International Journal of Culture, Tourism and Hospitality Research, 13(4), 505-523.

Wolfinbarger, M. and Gilly, M.C., 2003. eTailQ: Dimensionalizing, Measuring and Predicting Etail Quality. Journal of Retailing, 79(3), 183-198.

Yaghmaei, F., 2003. Content validity and its estimation. Journal of Medical Education, 3(1), 25-27.

Zeithaml, V. A., 1988. Consumer perceptions of price, quality, and value: a means-end model and synthesis of evidence. The Journal of Marketing, 52(3), 2-22.

Zhou, L., Dai, L., and Zhang, D., 2007. Online shopping, acceptance model - a critical survey of consumer factors in online shopping. Journal of Electronic Commerce Research, 8(1), 41. 


\section{APPENDIX 1. PSYHOMETRIC CHARACTERISTICS OF CONCEPTS MEASUREMENT}

Reliability and convergent validity

\begin{tabular}{|c|c|c|c|c|}
\hline Factor & Loads & $\mathrm{CA}$ & CR & AVE \\
\hline F1 Convenience & 1.000 & 1.000 & 1.000 & 1.000 \\
\hline F2 Hedonism & 1.000 & 1.000 & 1.000 & 1.000 \\
\hline F3 Booking facilites & 1.000 & 1.000 & 1.000 & 1.000 \\
\hline \multirow[t]{2}{*}{ F4 Accom. service select } & $0.960^{* *}$ & 0.840 & 0.922 & 0.856 \\
\hline & $0.889^{* *}$ & & & \\
\hline \multirow[t]{4}{*}{ F5 Past experience } & $0.883^{\star *}$ & 0.772 & 0.855 & 0.601 \\
\hline & $0.849^{* *}$ & & & \\
\hline & $0.735^{\star \star}$ & & & \\
\hline & $0.603^{* *}$ & & & \\
\hline \multirow[t]{5}{*}{ F6 Financial risk } & $0.806^{* *}$ & 0.846 & 0.870 & 0.588 \\
\hline & $0.861^{\star *}$ & & & \\
\hline & $0.371^{*}$ & & & \\
\hline & $0.841^{\star *}$ & & & \\
\hline & $0.840^{* *}$ & & & \\
\hline \multirow[t]{4}{*}{ F7 Service risk } & $0.827^{\star *}$ & 0.788 & 0.843 & 0.575 \\
\hline & $0.663^{\star *}$ & & & \\
\hline & $0.802^{* *}$ & & & \\
\hline & $0.732^{\star *}$ & & & \\
\hline \multirow[t]{3}{*}{ F8 Time risk } & $0.891^{\star *}$ & 0.798 & 0.880 & 0.710 \\
\hline & $0.859^{* *}$ & & & \\
\hline & $0.772^{\star *}$ & & & \\
\hline \multirow[t]{5}{*}{ F9 Guest Intentions } & $0.809^{\star *}$ & 0.929 & 0.947 & 0.780 \\
\hline & $0.897^{\star *}$ & & & \\
\hline & $0.889^{* *}$ & & & \\
\hline & $0.925^{\star \star}$ & & & \\
\hline & $0.892^{\star *}$ & & & \\
\hline \multirow[t]{3}{*}{ F10 Behavioural price } & $0.789^{* *}$ & 0.814 & 0.890 & 0.729 \\
\hline & $0.882^{* *}$ & & & \\
\hline & $0.888^{* *}$ & & & \\
\hline
\end{tabular}

\section{Discriminant Validity}

\begin{tabular}{|c|c|c|c|c|c|c|c|c|c|c|}
\hline & F1 & F2 & F3 & F4 & F5 & F6 & F7 & F8 & F9 & F10 \\
\hline F1 Convenience & 1.000 & & & & & & & & & \\
\hline F2 Hedonism & 0.066 & 1.000 & & & & & & & & \\
\hline F3 Booking facilities & 0.041 & 0.017 & 1.000 & & & & & & & \\
\hline F4 Accom. service selection & 0.018 & 0.074 & 0.432 & 0.856 & & & & & & \\
\hline F5 Past experience & 0.002 & 0.000 & 0.040 & 0.047 & 0.601 & & & & & \\
\hline F6 Financial risk & 0.030 & 0.016 & 0.143 & 0.182 & 0.121 & 0.588 & & & & \\
\hline F7 Service risk & 0.029 & 0.010 & 0.091 & 0.135 & 0.050 & 0.353 & 0.575 & & & \\
\hline F8 Time risk & 0.017 & 0.003 & 0.209 & 0.139 & 0.037 & 0.201 & 0.140 & 0.710 & & \\
\hline F9 Guest intentions & 0.025 & 0.050 & 0.065 & 0.144 & 0.280 & 0.030 & 0.079 & 0.050 & 0.780 & \\
\hline F10 Behavioural price & 0.000 & 0.003 & 0.069 & 0.053 & 0.241 & 0.103 & 0.020 & 0.146 & 0.257 & 0.729 \\
\hline
\end{tabular}

Note: Below the diagonal, estimated correlation between factors squared. On the diagonal, index of the variance extracted (AVE) 